\title{
Demography of Staff in Admistration Office of Universitas Negeri Medan
}

\author{
Restu $^{1}$, Syamsul Gultom², Hermawan Syahputra ${ }^{3 *}$ \\ 1)Department of Geography, Universitas Negeri Medan, Indonesia \\ ${ }^{2)}$ Department of Sport Science, Universitas Negeri Medan, Indonesia \\ ${ }^{3)}$ Department of Mathematics, Universitas Negeri Medan, Indonesia \\ *hsyahputra@unimed.ac.id
}

\begin{abstract}
This study aims to 1) map the suitability of office staff competencies with their educational backgrounds; 2) map the workload of office staff to their income; 3) mapping the suitability of the office staff's income and their daily needs; and map the lives of commuter office staff at the Universitas Negeri Medan. This study was conducted by survey method and descriptive statistics. Samples were taken at random from the population who were office staff at the administrative headquarters. Of the 100 instruments distributed, 52 returned. The results of the analysis indicate that there is still potential for staff development, especially in the field of competency certification. on the other hand there are opportunities for the development of welfare regulations. The results of this study will be useful for analyzing the suitability of the teaching staff and work units, analyzing the needs of office staff development, and developing management strategies and office staff development.
\end{abstract}

Keywords: Staff Management, Competencies Management, Higher Education.

\section{Introduction}

Human resources (HR) have an important role in the progress of an organization, including Government organizations. In Law Number 5 of 2014 [1] concerning State Civil Apparatus (in Language: ASN) it has been stated that ASN Employees are the main elements in realizing the national objectives listed in the opening of the 1945 Constitution. In the ASN Law it also states that ASN Employees have the task of carrying out public service tasks, governmental duties and certain development tasks to improve the welfare and prosperity of the whole community. Under these circumstances HR management no longer places employees as a burden that consumes the budget, but places employees as the main assets of the organization that have an important and strategic role. Changes in the style of HR management also occur in organizations in the Government where currently many Government organizations refer to their employees as human assets (Human Capital) and their management is referred to as Human Capital Management (HCM). However, the problem is whether human resources in the organization have truly been considered as the main assets of the organization. If it has been referred to as the main asset, whether in daily human resource management practices it has been treated as a human asset that needs to be fostered and developed like other valuable assets.

If it is true that employees are the main resources and assets, efforts should be made to improve and develop human capital optimally by involving all parts of the organization so that it is not merely a discourse to entertain and improve employee morale [2]. if only as a discourse

ICONSEIR 2019, December 17, Medan, Indonesia

Copyright $\odot 2020$ EAI

DOI 10.4108/eai.17-12-2019.2296051 
then the impact will be a time bomb where employees can be apathetic towards various HR development efforts in the future, even with the use of various good terms.

As an asset for the organization, HR must be managed and developed well as an investment for the organization in the hope that the investment can return to the organization at a higher value, or have a high return on investment. Managing HR assets is not the same as managing other assets. Humans are creatures that have knowledge, skills, personalities, self-concepts and motives that are not owned by other assets. To develop and invest in HR assets requires a special approach and must be carried out through stages ranging from planning to good evaluation if you do not want the development and investment of HR assets to be a futile activity.

Naturally, each ASN employee has his own experience, competency profile, qualifications, expertise, and potential that sometimes varies between ASN employees so that the impact on programs and competency development needs are different for each ASN Employee. Identification of HR development needs is needed so that HR asset development programs and activities are right on target, effective and efficient. Identification of needs is not only done at the organizational and work unit level, but also needs to be done for each ASN Employee while still considering employee career development.

Errors in developing human resources can be interpreted as doing work in vain, even potentially causing harm to the organization. In a study and observations made on various organizations, $80 \%$ of the work of an organization is often determined by $20 \%$ of employees in the organization. Reflecting on this, the identification of potential employees, who can deliver top achievements for the organization must be carried out carefully, carefully assessed and developed in accordance with well-planned programs and activities in order to provide maximum results [3]. on the other hand, organizational culture is known to shape lower employee performance compared to HR management and employee engagement. The employee engagement variable has the most influence on employee performance [4]. This indicates that employees who have an emotional attachment to their organization will tend to work well. So that policies can be directed at maximizing the composition of employees who work with the optimum and spur optimization of performance by increasing opportunities for employee emotional attachment to their institutions.

From the description above, it can be concluded that HR development is the main work that must be done for organizations that apply Human Capital Management in HR management. However, to make policies in management, accurate information is needed so that policy making is accurate and right on target. This study is a preliminary study that seeks to map the existing competencies possessed by educational staff in the State University of Medan. The mapping results will then be useful to determine what competencies are needed for a particular task field and what competencies need to be adjusted to the task field of an educational staff. Mapping will also be associated with the welfare and commuter life patterns of the education staff. These findings are expected to have implications for careful policy making and considering various aspects of the characteristics of the education workforce.

\section{Research Method}

This research was conducted by survey method in the office staff in Medan State University. Data collection was carried out with the help of a questionnaire with random sampling techniques in the population. With this technique this study succeeded in gathering 52 responses. Of the overall responses there were $53.84 \%$ responses from male tendons and another $46.15 \%$ from female tendons. Furthermore $32.69 \%$ of respondents aged $20-29$ years, $38.46 \%$ aged $30-39$ years, $25 \%$ aged $40-49$ years, and $3.84 \%$ aged $>50$ years. Respondents were divided 
almost evenly between respondents with civil servant status (53.84\%) and contract status (46.15\%). Then from a marital standpoint $17.30 \%$ of respondents are single, $32.69 \%$ of respondents are married, $44.23 \%$ are married and have children, and $5.76 \%$ of respondents are Widowed.

From this profile it can be assumed that although the number of samples is fairly limited, variations in the sample are quite varied, tiered, and evenly distributed across almost all demographic indicators namely in the categories of gender, age, employment status, and marital status. Thus variations in data still have a level of confidence referring to the distribution of samples in each category. That is, each category has representation in providing perceptions and conditions of various matters related to suitability of competence, suitability of workload and welfare, and the commuter life.

Table 1. Demograpyof Sample

\begin{tabular}{|c|c|c|c|}
\hline No & Indicators & $\mathbf{N}$ & $\%$ \\
\hline \multicolumn{4}{|l|}{ Gender } \\
\hline 1 & Male & 28 & 53,84 \\
\hline \multirow[t]{2}{*}{0} & Female & 24 & 46,16 \\
\hline & Total & 52 & 100 \\
\hline \multicolumn{4}{|l|}{ Age } \\
\hline 1 & $20-29$ & 17 & 32,69 \\
\hline 2 & $30-39$ & 20 & 38,46 \\
\hline 3 & $40-49$ & 13 & 25 \\
\hline \multirow[t]{2}{*}{4} & $>50$ & 2 & 3,84 \\
\hline & Total & 52 & 100 \\
\hline \multicolumn{4}{|l|}{ Status } \\
\hline 1 & Civil Servants & 28 & 53,84 \\
\hline \multirow[t]{2}{*}{0} & Contract & 24 & 46,15 \\
\hline & Total & 52 & 100 \\
\hline \multicolumn{4}{|c|}{ Marital Status } \\
\hline 1 & Single & 9 & 17,30 \\
\hline 2 & Married & 17 & 32,69 \\
\hline 3 & Married with Children & 23 & 44,23 \\
\hline \multirow[t]{2}{*}{4} & Divorce & 3 & 5,76 \\
\hline & Total & 52 & 100 \\
\hline
\end{tabular}

\section{Results and Discussion}

Snapshoot of Office Staff Profile

To achieve the objectives of this study, researchers tabulated the survey data into snapshoot profiles of Office Staff. The profile is distributed into three parts, namely 1) the suitability of competencies with the task field; 2) Suitability of workload with welfare; and 3) Profile of commuter life.

\section{Conformity of Competence with the Field of Duty}

Table 5.2 presents the results of the tabulation of data related to the perception of the suitability of the field of duties of educational staff and their educational backgrounds. The results showed that $71.15 \%$ of the education staff claimed that their educational background was in line with the task area they were responsible for at present while another $28.85 \%$ felt they were not. Of the $28.85 \%$ tendik who feel that their educational background is not in accordance with their field of work, $6.67 \%$ or dama with one person claimed to get expertise related to their field of duty through training, while 4 of them or $26.67 \%$ claimed to get expertise through an internship , and 10 other people or $66.67 \%$ claimed to get expertise in their field of work in a 
self-taught manner. This shows that minor structuring related to the distribution of tendins is needed according to their field of work, or structured and systematic training so that tendons that have a field of assignment not in accordance with their educational background can have special competencies related to their task area so that their performance can be of higher quality.

Furthermore, the researcher also identifies whether the task area in charge of the tendon requires a certificate of competence. $48.08 \%$ of respondents claimed that their field of work needed a certificate of competence, while another $51.92 \%$ claimed that their field of work did not require a certificate of competency. Furthermore, $32.69 \%$ of them or 17 people claimed to have had a competency certificate while another $67.31 \%$ or 35 people claimed not to have a competency certificate. Of the 17 respondents who already had competency certificates 16 of them had 1 (one) competency certificate while the other two had 2 (two) and 3 (three) competency certificates.

Based on the profile it is known that there are still a small number of tendics who have competency certificates even though this part has fulfilled a large portion of the competency certificate requirements according to the field of assignment that requires it. However, in improving work quality assurance it is also necessary to consider increasing the tendency capacity by including the tendency in competency certification. So that organizational performance is expected to be better with the assurance of competencies possessed by Tendik. Including a tendency in professional training can be categorized as an investment in human capital or intellectual capital.

Table 2. The Suitability of Competencies with Task Field

\begin{tabular}{|c|c|c|c|}
\hline Dummy & Indicators & $\mathbf{N}$ & $\%$ \\
\hline \multicolumn{4}{|c|}{ Suitability of Educational Background with Field of Work } \\
\hline 1 & Suitable & 37 & 71,15 \\
\hline \multirow[t]{2}{*}{0} & Not suitable & 15 & 28,85 \\
\hline & Total & 52 & 100 \\
\hline \multicolumn{4}{|c|}{ Education and Training Programs in accordance with the Field of Duty } \\
\hline 1 & Training & 1 & 6,67 \\
\hline 2 & Internship & 4 & 26,67 \\
\hline \multirow[t]{2}{*}{3} & Autodidact & 10 & 66,67 \\
\hline & Total & 15 & 100 \\
\hline \multicolumn{4}{|c|}{ Does the Task Field Require a Competency Certificate } \\
\hline 1 & Yes & 25 & 48,08 \\
\hline \multirow[t]{2}{*}{0} & No & 27 & 51,92 \\
\hline & Total & 52 & 100 \\
\hline \multicolumn{4}{|c|}{ Do You Have a Competency Certificate } \\
\hline 1 & Yes I Do Have & 17 & 32,69 \\
\hline 0 & Not Yet & 35 & 67,31 \\
\hline & Total & 52 & 100 \\
\hline \multicolumn{4}{|c|}{ Number of Competency Certificates Held } \\
\hline 1 & 1 & 16 & 88,89 \\
\hline 2 & 2 & 1 & 5,56 \\
\hline 3 & 3 & 1 & 5,56 \\
\hline 4 & 4 & 0 & 0 \\
\hline 5 & $>4$ & 0 & 0 \\
\hline \multicolumn{2}{|r|}{ Total } & 18 & 100 \\
\hline
\end{tabular}

\section{Suitability of Workload with Staff Welfare}

Furthermore, in table 5.3 it appears that the majority of tendics, i.e. $86.53 \%$ perceive that the income they have is commensurate with the workload they are responsible for, while the 
remaining $13.46 \%$ feel disproportionate and no respondent claims to be very commensurate. When viewed from the appropriateness of income with the daily needs of the respondents, the previous figure turned out to be $69.23 \%$ of the respondents felt that they were appropriate or sufficient, $30.77 \%$ felt inadequate.

Table 3. Perception of Approprietness Workload and Welfare

\begin{tabular}{|c|c|c|c|}
\hline Dummy & Indicators & $\mathbf{N}$ & $\%$ \\
\hline \multicolumn{4}{|c|}{ Income equivalent to workload } \\
\hline 1 & Not Worth it & 7 & 13,46 \\
\hline 2 & Worth it & 45 & 86,54 \\
\hline \multirow[t]{2}{*}{3} & Very Worth it & 0 & 0 \\
\hline & Total & 52 & 100 \\
\hline \multicolumn{4}{|c|}{ Income is sufficient for daily needs } \\
\hline 1 & Insufficient & 16 & 30,76 \\
\hline 2 & Sufficient & 36 & 69,24 \\
\hline \multirow[t]{2}{*}{3} & Very Sufficient & 0 & 0 \\
\hline & Total & 52 & 100 \\
\hline \multicolumn{4}{|c|}{ Do Respondents Have Additional Jobs } \\
\hline 1 & Yes & 6 & 11,54 \\
\hline 0 & No & 46 & 88,46 \\
\hline $\mathrm{S}$ & Total & 52 & 100 \\
\hline \multicolumn{4}{|c|}{ Does the wife / husband work? } \\
\hline 1 & Yes & 22 & 42,31 \\
\hline 0 & No & 10 & 19,23 \\
\hline \multirow[t]{2}{*}{ - } & Abstain & 20 & 38,46 \\
\hline & Total & 52 & 100 \\
\hline \multicolumn{4}{|c|}{ Spouse Job } \\
\hline 1 & ASN (Teacher/Lecturer) & 4 & 18,18 \\
\hline 2 & ASN (Office Staff) & 5 & 22,72 \\
\hline 3 & Teacher/Lecturer (Private School) & 3 & 13,63 \\
\hline 4 & Office Staff (Private Organization) & 8 & 36,36 \\
\hline \multirow[t]{2}{*}{5} & Entrepreneur & 2 & 9,09 \\
\hline & Total & 22 & 100 \\
\hline
\end{tabular}

This happens because the basis for the suitability consideration is different, in the second part the suitability is weighed based on daily needs, which of course each respondent has different requirements criteria referring to his demography, for example marital status and marital partner's work profile which certainly determines the number of dependents in the family and income distribution on these dependents. Therefore in this section the question is deepened on whether the respondent has additional work and whether the spouse (husband / wife) works or not. $11.53 \%$ of respondents claimed to have additional work and $42.31 \%$ of respondents claimed that their partners also worked. So that $19.23 \%$ claimed their partners did not work and $38.46 \%$ abstained. From this figure it becomes rational if $30.77 \%$ of respondents feel that their income is insufficient for their daily needs. This finding can be taken into consideration in adjusting the bonus scheme based on more complex variables according to the demographics, working conditions, and workload of each prop to ensure better distribution of welfare.

\section{Profile of Commuters Life of Office Staff}


In this section basically the researcher not only identifies the profile of the tendered kemuter, but more than that explores aspects that might cause a commuter profile to form. First of all the researchers identified the profile of the tendon's residence, $50 \%$ of the tendis claimed to have lived in their own home, while $13.46 \%$ claimed to live in a rented house, and $36.54 \%$ claimed to live in a family home. Then the analysis is sharpened to the distance from home to office. $15.38 \%$ of respondents said that they were less than $5 \mathrm{~km}$ from the office, $46.15 \%$ claimed they lived 5-10 km from the office, 25\% claimed they lived 10-20 km from the office, $7.69 \%$ claimed they lived $20-30 \%$ from the campus , and $5.77 \%$ claimed $>30 \mathrm{~km}$ from the office. Furthermore, based on travel time, $9.62 \%$ of respondents claimed to need less than 10 minutes to get to the office, $32.69 \%$ claimed to need $11-20$ minutes, $30.77 \%$ claimed to need $20-30$ minutes, $15.38 \%$ claimed to need $30-50$ minutes, and $11.54 \%$ claimed to need more than 50 minutes to get to the office from where they live.

To deepen the situation, the researchers also reviewed the modes of transportation owned and used by the prop to get to the office. $53.85 \%$ of respondents claimed not to have a car, $36.54 \%$ claimed to have one car, $5.77 \%$ claimed to have two cars, and $3.85 \%$ claimed to have more than 2 cars. For motorcycle ownership, $9.62 \%$ of respondents claimed not to have a motorcycle, $63.46 \%$ claimed to have one motorbike unit, $21.15 \%$ had two motorbikes, and $5.77 \%$ had more than two motorbikes. Finally, the profile of transportation modes used by respondents shows that $5.77 \%$ of respondents use public transportation to go to work, $88.46 \%$ of respondents use private vehicles, and $5.77 \%$ use taxis / motorcycle taxis online.

The commuter's life profile can indicate the efficiency and effectiveness of tendency mobility to carry out tasks and drained energy to get to the office. The lack of distance and travel time will reduce wasted energy and maintain the quality and concentration of tendik work in the office. The efficiency and effectiveness of commuting can then be associated with welfare distribution. Welfare will be associated with the ability of Tendik to own private vehicles and subsequently have their own dwellings. Owning a private vehicle certainly increases tendency mobility and occupancy ownership will increase the comfort and quality of life of the tendon which in turn will increase work comfort. So that the quality of tendik work can be maintained. The policy that can be developed from this figure is the opportunity to easily have a dwelling or private vehicle with funding or financing programs. Efforts to develop these programs further require a feasibility study to be truly targeted and touch on the actual problems faced in improving the efficiency of the life of the tendered commuter. The commuter's life profile can be generally reviewed in table 5.4 below.

Table 4. Profile of Commuter Life

\begin{tabular}{cccc}
\hline Variable & Indicators & $\mathbf{N}$ & \% \\
\hline Residence & & & \\
1 & My own house & 26 & 50,00 \\
2 & Rented house & 7 & 13,46 \\
3 & Family house & 19 & 36,54 \\
\hline Total & & 52 & 100,00 \\
Distance from Home to the Office & & \\
\hline 1 & $<5 \mathrm{~km}$ & 8 & 15,38 \\
2 & $5-10 \mathrm{~km}$ & 13 & 46,15 \\
3 & $10-20 \mathrm{~km}$ & 4 & 25,00 \\
4 & $20-30 \mathrm{~km}$ & 3 & 7,69 \\
5 & $>30 \mathrm{~km}$ & 52 & 5,77 \\
\hline Jumlah & & & 100,00
\end{tabular}




\begin{tabular}{|c|c|c|c|}
\hline Variable & Indicators & $\mathbf{N}$ & $\%$ \\
\hline \multicolumn{4}{|c|}{ Travel Time from Home to the Office } \\
\hline 1 & $<=10$ minute & 5 & 9,62 \\
\hline 2 & $11-20$ minute & 17 & 32,69 \\
\hline 3 & 20-30 minute & 16 & 30,77 \\
\hline 4 & $30-50$ minute & 8 & 15,38 \\
\hline 5 & $>=50$ minute & 6 & 11,54 \\
\hline Total & & 52 & 100,00 \\
\hline \multicolumn{4}{|c|}{ Number of Car Owned } \\
\hline 1 & 0 & 28 & 53,85 \\
\hline 2 & 1 & 19 & 36,54 \\
\hline 3 & 2 & 3 & 5,77 \\
\hline 4 & $>2$ & 2 & 3,85 \\
\hline Total & & 52 & 100,00 \\
\hline \multicolumn{4}{|c|}{ Number of Motorcycle Owned } \\
\hline 1 & 0 & 5 & 9,62 \\
\hline 2 & 1 & 33 & 63,46 \\
\hline 3 & 2 & 11 & 21,15 \\
\hline 4 & $>2$ & 3 & 5,77 \\
\hline Total & & 52 & 100,00 \\
\hline \multicolumn{4}{|c|}{ Modes of Transportation used to get to the office } \\
\hline 1 & Mass Transport & 3 & 5,77 \\
\hline 2 & Private Vehicle & 46 & 88,46 \\
\hline 3 & Online Taxi & 3 & 5,77 \\
\hline Total & & 52 & 100,00 \\
\hline
\end{tabular}

\section{Conclusion}

Based on the results of the study, it was detected that some education personnel who had task fields were not in accordance with their educational background and professional training was still needed to obtain a certificate of competence for education personnel whose field of work did require certified competence. Furthermore, at a low level there are still education personnel who perceive that their income is not sufficient for their daily lives. This has implications for the tendency for education staff to seek additional work. Finally, from the welfare aspect, it was identified that $50 \%$ of the teaching staff did not yet have their own place of residence and a car. While most already have a motorcycle. Based on these findings, a policy on competency structuring according to the task area is needed, competency enhancement with standard certified professional training, and regulation of compensation and bonus distribution in accordance with social conditions and performance of education staff in Medan State University.

\section{References}

[1] Undang-Undang Republik Indonesia Nomor 5 Tahun 2014 Tentang Aparatur Sipil Negara

[2] Collings, D.G and Wood, G. (2009). Human Resource Management, A critical approach. Taylor \& Francis e-Library.

[3] Davis, Tony (2009). Talent Assessment, Mengukur, Menilai, dan Menyeleksi OrangOrang Terbaik dalam Perusahaan (terjemahan). Jakarta: Penerbit PPM. 
[4] Permana,NinaInsaniaK,.(2010). Talent Management Implementation: Belajar dari Perusahaan-Perusahaan Terkemuka. Jakarta: Penerbit PPM. 